\title{
PERIFEERSEST KAUSATIIVSUSEST
}

\author{
GEDA PAULSEN
}

$\mathrm{P}$ õhjuslikkuse väljendamine on inimkeele ja üleüldse tajusüsteemi seisukohast üks inimesele omasemaid nähtusi: et ümbritsevast maailmast võimalikult hästi aru saada, püüame välja selgitada seoseid sündmuste ja neid käivitavate protsesside vahel. Põhjustamisel on mitu nägu: põhjustaja võib olla elus või elutu, mingi olukord võib olla esile kutsutud meelega või juhuslikult, tegemist võib olla otsese või kaudse põhjustamisega, samuti võib põhjustaja olla samaaegselt põhjustatud olukorra sihtmärk või eesmärk (vrd Aristotelese causa finalis ehk eesmärkpõhjus). Põhjustamise keeleline väljendusvorm ei ole otseses vastavuses füüsilise kolmemõõtmelise „reaalmaailma” protsessidega, vaid on pigem selle kontseptuaalne heiastus. Siiski, nagu Michael Tomasello (1999) rõhutab, arusaam kausaalprotsessidest mõjutab keelelist väljendusvormi ning keele abil mõistestame füüsilist, psühholoogilist ning kultuurilist põhjuslikkust.

Keeleteaduses kutsutakse põhjustamist väljendavaid keelendeid kausatiivideks ning neid määratletakse sageli raamis, mis defineerib põhjustamist valentsi lisava süntaktilise protsessina. Kasutan siinses artiklis keeleliste nähtuste käsitlemisel sünonüümseid mõisteid põhjustamine ja kausatiivsus. Termin kausatiivsus on siin kasutusel laiemas tähenduses kui neil keeleteadlastel, kes piiritlevad seda nähtust süntaktilise tuletusprotsessiga. Kuna käsitlen põhjustamist semantilisest vaatenurgast, kirjutan ka põhjustest, põhjussuhetest, põhjusseostest ning põhjustähendustest. Kausatiivseks väljendiks kitsa käsitluse järgi saab pidada niisiis lauset Orav kukutas käbi maha taustaoletusega, et see on tuletatud lausest Käbi kukkus maha uue subjektargumendi lisamise teel. Valentsil põhineva definitsiooni esitab näiteks Robert Dixon (2000: 30): „...kausatiivkonstruktsioon lisab tuumlausesse põhjustajaargumendi. Põhjustaja viitab kellelegi või millelegi (mis võib olla sündmus või seisund), mis algatab või kontrollib tegevust.” Ka Mati Erelt määratleb eesti grammatikakirjelduses kausatiive tuletusprotsessi tulemusena: „Mõningaid argumentstruktuuri kujundusi ehk argumentkonstruktsioone saab markeerida verbis muutelõppude asemel tuletussufiksitega. [---] Sellised tüüpjuhul tuletusliku (liitelise) vormistusega verbikategooriad ja vastavad argumenttarindid on kausatiiv, antikausatiiv ehk inhoatiiv ja refleksiiv. Kausatiivil ja antikausatiivil on seejuures paralleelselt võimalik ning tuletuslikust levinumgi ka perifrastiline vormistus” (Erelt 2013: 208) ning „Kahe sündmuse ühendamist kausatiivtarindi moodustamisel käsitatakse... predikaadi valentsi suurendava ja argumentstruktuuri muutva operatsioonina" (Erelt 2013: 209).

Funktsionaalsemast vaatenurgast räägitakse kahe sündmuse vahelisest põhjuslikust sõltuvusseosest ning kausatiivsuse üks postulaate on, et põhjustatud sündmus ei saa eksisteerida ilma põhjustava sündmuseta (nt Shibatani 1976) või isiku tegutsemiseta (ingl the person's action, Talmy 1976). Nii näevad kausatiivsust põhjustava ja põhjustatud sündmuse vahelise seosena näiteks Dowty (1979), Foley ja van Valin (1984) ning Shibatani (1976). Nee- 
leman ja van de Koot (2012) aga kummutavad põhjustava sündmuse oletuse kausatiivsete verbide süntaktilise või leksikaalsemantilise representatsiooni osana ning defineerivad keelelise põhjustamise tulemusseisundi (ingl resultant state) ja selle seisundi tekkele otsustavalt kaasa aitava teguri (ingl crucial contributory factor) kaudu.

Siinses artiklis püüan näidata, et ka väljaspool tuletuse põhjal defineeritud ala leidub mitmesuguseid kausatiivsusega seotud keelelisi nähtusi, mille vorme, tähendust ja omavahelisi seoseid on otstarbekas täpsemalt välja selgitada. Ma ei käsitle kausatiivsust tingimata kahe sündmuse vahelise seosena, vaid põhjuse ja tulemuse/tagajärje suhtena: põhjussuhe tekib kahe olukorra (sündmuse või seisundi) või põhjustaja ja olukorra vahel, kui põhjus viib mingi teise olukorra, tagajärjeni. Tulemusolukorra teke sõltub niisiis põhjuse esinemisest. Nii ei väljenda kausatiivsust näiteks propositsioonid Süsteem on selle koha pealt vigane või Põlvamaa on soode poolest rikas - neis lauseis on kahe temaatilise osaleja vahel mingit tüüpi korrelatsiooni-, mitte põhjussuhe. Kahe sündmuse vahelist põhjussuhet iseloomustab lause 1, kus olukord nekruteid ähvardas pikk kroonuteenistus põhjustab olukorra nekrutid pagesid. Lauses 1' on olukorra Jüri läheb trellide taha põhjustaja temaatiline osalejaargument Mats. Lause tähendusest ei selgu, mida Mats tegi, et Jüri trellide taha läks, kuid oluline on, et ilma Matsita seda poleks juhtunud.

\section{(1) Nekrutid pagesid, kuna neid ähvardas pikk kroonuteenistus.}

(1') Mats saatis Jüri trellide taha.

Kausatiivsusel on keeles erinevaid väljendusvorme; põhjussuhete kaudu propositsioonide sidumine on $\mathrm{mh}$ üks kohesiooni loomise võimalusi. Laias plaanis võiks põhjustamise väljendusvahendid jaotada eksplitsiitseteks kausatiivideks (vormid, mille põhifunktsiooniks on põhjusseoste väljendamine, nagu eesti keeles kaassõnad tõttu ja pärast) ja implitsiitseteks kausatiivideks (vormid, mis väljendavad põhjustähendust sekundaarselt, eesti keeles näiteks kohakäänded: Kuningas hukkus lennuõnnetuses). Seega on ka eesti keeles kausatiivsus kompleksne leksikaalgrammatiline nähtus. Kausatiivsuse süntaktilise määratluse domineerimise tõttu võib väita, et põhiliselt on keeleuurijate tähelepanu köitnud tuumlause ehk argumentstruktuuri piiridesse jäävad kausatiivitüübid: leksikaalsed (tapma, lükkama), morfoloogilised (vaju-ta-ma, hääle-ta-ma) ja analüütilised (Õpetaja lasi poisil joosta) kausatiivkeelendid, mis on esindatud ka eesti keeles. ${ }^{1}$

Kausatiivsust saab aga väljendada ka mitmesuguste tuumlausest väljapoole jäävate adverbiaalkonstruktsioonidega, mis moodustab mitmetahulise ning vähem uuritud ala keeleteaduses. Nn perifeersete kausatiividena on eesti keeles samuti kasutusel nii leksikaalsed (proadverbid miks, mistõttu, mispärast, misläbi; sellepärast, seetõttu, seeläbi et, et jne), sünteetilised (semantilised käänded, nt Kuningas suri mürgitusse) kui ka analüütilised (kaassõnad, nt Kuningas suri mürgituse tõttu) väljendusvahendid. Kausatiivsust väljendavad ka mitmesugused konverbikonstruktsioonid (Kosmonaut lendas kuule kraatreid uurima, Castafiore ei saa proovi tegemata/rattaga sõites „Juveeli-

${ }^{1}$ Kausatiive on käsitlenud nt Reet Kasik (2001, 2014 ja 2015) ja Mati Erelt (2013), kausaalseid adverbiaallauseid Helen Plado (2013). 
aariat" laulda) ${ }^{2}$ ja deverbaalsed nominalisatsioonkonstruktsioonid (Ahven lagunes keetmisel). Lisaks komplitseerib olukorda mittekausatiivsete verbide kasutamine kausatiivse tähendusega konstruktsioonides, nagu näiteks konstruktsioon $X$ taga on $Y$ järgmises uudispealkirjas:

(2) Õhuväe ülem: droonid ei otsusta tappa, selle otsuse taga on alati inimene. (http://uudised.err.ee/v/eesti/405a9f1b-2cd3-427b-ad61-63cd 04756484)

Artiklis avan perifeerse kausatiivsuse väljendusvahenditega seotud küsimusi, pretendeerimata teema ammendavale käsitlusele. Keskendun eesti keele sünteetilistele (käändelistele) ja analüütilistele (kaassõnalistele) põhjust tähistavatele adverbiaalkonstruktsioonidele; käsitlusele tulevad põgusalt ka infinitiiv- ja genitiivatribuutkonstruktsioonid (ptk 3.3). Määratlen perifeerseid kausatiivtarindeid adjunktidena ${ }^{3}$ mis annavad edasi maatrikslauses väljendatud situatsiooni põhjust. Kirjeldan aja- ja põhjussuhete vastastikmõju, mille teoreetilis-metodoloogiline eesmärk on esitada mittelineaarse kausatiivsuse mall kontseptuaalse semantika teoreetilisele raamistikule tuginedes. Põhjus- ja ajasuhete tüüpide põhjal liigitan käsitletavad adjunktid põhjusadjunktideks (maatrikslause põhjust väljendavad adjunktid, ptk 3), tagajärgadjunktideks (maatrikslause tagajärge väljendavad adjunktid, ptk 4) ja otstarbeadjunktideks (kahesuunalist põhjustamist väljendavad adjunktid, ptk 5). Kõigi põhjustamisega seotud adjunktide üldnimetusena kasutan mõistet kausatiivsed adjunktid. Vähema tähelepanu osaliseks saavad põhjustähenduse loomisel osalevad semantilised komponendid, nagu lause temaatiline struktuur, agendi-patsiendi omadused (kontroll, tahtlikkus, teadlikkus, vastutus jne), semantilised väljad jne. Käsitlusalast jäävad välja kausatiivsust väljendavad kõrvallaused.

\section{Sünteetiliste ja analüütiliste kausatiivsete adjunktide vormist}

Adjunkti mõiste defineerimisel on enamasti lähtutud n-ö eitavast positsioonist: kui argumendid on lause kesksed, obligatoorsed moodustajad, siis adjunktid ei ole verbi valitud lauseliikmed, vaid mingil spetsiifilisel moel verbiga seotud keelendid, mis võivad olla ühendatud verbi argumentstruktuuriga (nt Lang jt 2003; Needham, Toivonen 2011). Adjunktid toovad niisiis lausesse lisainformatsiooni ja neid saab lausest välja jätta, rikkumata sealjuures lause grammatilisust. Eesti keeles saab põhjusadjunkt esineda peaaegu kõigis semantilistes käänetes. Näiteid põhjusadjunkte vormistavatest käändevormidest on esitatud tabelis 1 .

Teise, mõnikord sünteetilise fraasiga paralleelse võimaluse põhjusadjunktide väljendamiseks pakuvad erinevad kaassõnaühendid. Põhjust väljendatakse eesti keeles põhiliselt tagasõnade, aga ka eessõnade ning ka mõlemas funktsioonis esinevate kaassõnade abil. Lisaks on kasutusel kaassõnadega (postpositsioonidega) süntaktiliselt võrdväärseid adessiivseid, essiivseid või komitatiivseid nimisõnavorme (tagajärjel, tulemusena, eesmärgiga). Tabelis 2

\footnotetext{
${ }^{2}$ des-ja mata-konstruktsioone on käsitlenud Ellen Uuspõld 1966, Erelt 2014, Plado 2015; finaaladverbiaali vormide kohta vt Uuspõld 1980.

${ }^{3}$ Mittesüntaktiliste adverbiaalide kohta on käibel ka terminid täiend ja vaba laiend.
} 


\section{Sünteetilisi põhjusadjunkte vormistavad käänded}

\begin{tabular}{|l|l|}
\hline elatiiv & $\begin{array}{l}\text { Kuningas suri vanadusest / kopsupõletikust; } \\
\text { vrd *vigastusest / *operatsioonist / *mürgist / ?vangistusest. }\end{array}$ \\
\hline illatiiv & $\begin{array}{l}\text { Kuningas suri vanadusse / kopsupõletikku / vigastusse; } \\
\text { vrd *operatsiooni / *mürki / *vangistusse. }\end{array}$ \\
\hline adessiiv & $\begin{array}{l}\text { Kuningas suri operatsioonil; } \\
\text { vrd *vanadusel / *kopsupõletikul / *vigastusel /*vangistusel / *mürgil. }\end{array}$ \\
\hline inessiiv & Kuningas hukkus plahvatuses. Suurtes valudes pöördus kuningas arsti poole. \\
\hline allatiiv & Kuningas läheb haiglasse uuringutele. \\
\hline ablatiiv & $\begin{array}{l}\text { Kuningas tuleb haiglast uuringutelt. [Kui uuringuid poleks toimunud, ei } \\
\text { oleks kuningas pidanud haiglas käima.] }\end{array}$ \\
\hline translatiiv & Kosmonaut lendab Kuule kraatrite uurimiseks. \\
\hline komitatiiv & Elsa paistis silma töökuse ja andekusega. \\
\hline abessiiv & Ma ei suuda sinuta elada. Rahustita on Elsal raske uinuda. \\
\hline essiiv & Ajakirjanikuna kohtun paljude inimestega. \\
\hline
\end{tabular}

on esitatud põhjusadjunkte vormistavaid kaassõnu, jaotatuna nende lausefunktsiooni (ees- ja tagasõnad ning „paindlikud” ehk mõlemas rühmas esinevad kaassõnad) põhjal kolme suuremasse rühma. Põhjust väljendavate kaassõnade seas võib hoomata teatud sünonüümi-antonüümisuhteid, ka rühmade vahel, nt tagajärjel-tulenevalt / hoolimata, jaoks-vastu, saatel-koos/ilma. Tõden siinkohal, et tabelis 2 esitatud kaassõnade põhjalikum analüüs tuleb jätta tulevikuks, ka ei pretendeeri tabel ammendavale loendile.

Tabel 2.

\section{Analüütilisi põhjusadjunkte vormistavad kaassõnad ning kaassõnalise funktsiooniga adessiivsed/ essiivsed/komitatiivsed nimisõnavormid}

\begin{tabular}{|l|l|l|}
\hline Tagasõnad & Taga-/eessõnad & Eessõnad \\
\hline kätte, tõttu, mõjul, uhal, pärast, peale, & läbi & \\
põhjusel, teel, toel, jõul, & & \\
tagajärjel, tulemusel, tulemusena, & tulenevalt, hoolimata, & \\
tõukel, ajel, korral, puhul, pinnal, alusel, pinnalt; & vaatamata & \multirow{2}{*}{ ilma, tänu } \\
jaoks, tarbeks, tarvis, heaks, ees, eesmärgil, nimel; & & \\
pihta; eest; poolest; abil, abiga, toel, saatel, kaudu, & vastu & \\
käigus; taga (põhjusseisund); puudusel; & eesmärgiga & \\
käes, küüsis, all, kallal & koos & \\
\hline
\end{tabular}


Eesti keele grammatikas (EKG II: 95) on lühidalt loetletud põhjusmääruste vormilisi vahendeid koos näidetega. Kuna siinses töös käsitlen kausatiivsust laiemalt kui EKG, on ka tabelites 1 ja 2 esitatud kausatiivsete vormide hulk laiem. Tabelis 1 esitatud põhjust väljendavatest käändevormidest on EKG-s nimetatud elatiiv, illatiiv, adessiiv, komitatiiv ning abessiiv; mainitud ei ole essiivi, translatiivi, allatiivi, ablatiivi ega inessiivi. Kaassõnadest ning neile vastavatest nimisõnalistest vormidest on põhjusmäärust vormistavateks sõnadeks liigitatud pärast, tõttu, peale, kätte, läbi, eest, tänu; tagajärjel, mõjul, tulemusel, tulemusena. EKG-s põhjusmääruse väljendajatena mainitud vormid on tabelites 1 ja 2 märgitud paksus kirjas. Olen põhjusadjunktide vormistajate hulka arvanud ka traditsiooniliselt tingimus-, mööndus- ning otstarbemäärusi väljendavaid vorme, kuna nende tähenduses on esindatud kausatiivsus. Näiteks otstarbemäärused kujutavad endast kompleksset kahesuunalist aja-põhjussuhete kombinatsiooni, mille täpsema analüüsi juurde naasen peatükis 5 .

Üks esmapilgul silmatorkav kohakäändeliste põhjusadjunktide aspekt on see, et kui elatiiv ja illatiiv annavad selgelt põhjust väljendava adjunkti (näiteks surema-verbiga seotud põhjusadjunktifraasis), siis adessiivi, allatiivi, ablatiivi ja inessiiviga võivad kaasneda lisaks põhjustähendusele ka temporaalsed ja/või ruumilised implikatsioonid - põhjuslikkus ei paista mitte alati olevat nende ainuke tõlgendus. Kaassõnad aga erinevad üksteisest selle poolest, kas nad on puhtalt põhjustähenduslikud (tõttu, mõjul) või väljendavad põhjusseost ainult mingitel konstruktsioonipõhistel eritingimustel (nt koos ja ilma saavad põhjustähenduse eitavas modaalkonstruktsioonis Jüri ei saa elada ilma Marita / koos Mariga). Sünteetiliste ja analüütiliste põhjusadjunktide omavahelise distributsiooni kohta võib esialgsete tähelepanekute põhjal öelda, et sünteetilisel põhjusadjunktil ei pruugi olla analüütilist vastet (näide 3) ja vastupidi, kaassõnafraasi ei saa alati asendada sünteetilise põhjusadjunktiga (vrd näited 4-4"). Võrdluseks tuleb mainida, et ka lokatiivsed adjunktid ei ole alati asendatavad (näited 5-5').

(3) Mari puudus koolist mõjuvatel põhjustel /?mõjuvate põhjuste pärast.

(4) Õpetaja pahandas Jussiga hilinemise pärast.

(4') Jalavägi taandus tankide ees.

(4") Lavastaja tunneb aukartust Wagneri ees.

(5) Kalev tuleb poest / linnast / Soomest / koolist / lennukilt.

(5') Kalev tuleb *poe seest/*linna seest ${ }^{4} /{ }^{*}$ Soome seest/*kooli seest/lennuki pealt.

\section{Kausatiivsus ja aeg. Põhjusadjunkti ja maatrikslause ajasuhe}

Põhjustamise semantiline määratlus on tihedalt seotud ajalise mõõtmega: A kutsub esile B, eelnedes B-le. Põhjustaja tegevus või põhjustav sündmus peab niisiis eelnema tagajärjeks olevale situatsioonile. Kas aga keeleliste kausatiivkonstruktsioonide aja- ja põhjussuhted on alati kronoloogilises vastavuses? William Croft $(1991,1998,2009)$ on võtnud kasutusele nn lineaarse põhjusahela mudeli (ingl the linear causal chain), mis on tuletatud kausaaljärjendi kaudu, sisaldades ka sekundaarseid (adjunkt)struktuure. Crofti järgi mää-

\footnotetext{
${ }^{4}$ Siin on siiski võimalik käändeline linna pealt (tänan retsensenti tähelepaneku eest).
} 
ravad lause (sealjuures ka adjunktide) põhjussuhted (ja sündmusstruktuur) otseselt lause argumentstruktuuri, vastates reeglile, mille järgi tüpoloogiliselt lause grammatiline subjekt eelneb põhjusahelas objektile. ${ }^{5}$ Crofti mudel on mõjutatud Talmy $(1976,1988)$ jõudünaamika (ingl force dynamics) teooriast ja seda saab kokku võtta väitega, et osavõtjate relatiivne positsioon sündmuses on määratud jõu liikumisega. Seda mudelit illustreerib näide 6 (vt Croft 1991: 177, aga ka Croft 2009 ja 2012); termin antecedent oblique tähistab Crofti teoorias objektile eelnevat ja subsequent oblique objektile järgnevat obliikvat ehk mittegrammatilistes käänetes vormistuvat seotud laiendit.

(6) Sue broke the coconut for Greg with a hammer.

'Sue lõi Gregile kookospähkli haamriga katki.'

\begin{tabular}{|c|c|c|c|c|}
\hline Sue & $\rightarrow$ & haamer & $\rightarrow$ & kookospähkel \\
\hline subjekt & & $\begin{array}{c}\text { eelnev } \\
\text { obliikva }\end{array}$ & & objekt \\
\hline
\end{tabular}

Crofti põhjusahela mudelile vastab Ronald Langackeri (1991) tegevusahel (ingl action chain), mille aluseks on idee, et on olemas energia läte (ingl energy source) ja saba (ingl energy sink 'äravool') ehk ots jada lõpus, millest energia enam edasi ei liigu. Peamine roll on niisiis lähemalt määratlemata omadustega energial. Tegevusahelat võib kujutada järgmiselt:

LÄTE $\rightarrow$ ASI $\rightarrow$ ASI $\rightarrow$ ASI $\rightarrow$ ASI $\rightarrow$ OTS

Kontseptuaalses semantikas (Jackendoff 1990, 1997, 2010; Nikanne 1990, 1997, 2008; Pörn 2004, 2008; Paulsen 2011, 2013) on aja- ja põhjussuhted üksteisest eraldatud. Sündmuse sisemiste ajasuhete analüüsis kasutab Ray Jackendoff $(1987,1990)$ temporaalstruktuuri (ingl temporal tier või T-tier) mõistet, mis kujutab ajadimensiooni kahe primitiivi, ajapunkti $(\mathrm{P})$ ja ajajoone $(\mathrm{R})$, abil. Ajastruktuur võib koosneda ainult punktist või ainult joonest, see võib olla piiritletud alguses (PR), lõpus (RP) või ka ajajoone keskel (RPR). Komplekssete kausatiivsust sisaldavate sündmuste ajastruktuuri võib analüüsida põhjustava ja põhjustatud sündmuse ajalise seosena. Toetudes Michotte’i põhjuslikkuse tajutüüpidele (1954, viidatud Jackendoff 1990 kaudu), jagab Jackendoff põhjustamise ajastruktuuri kaheks: a) kaasamine (ingl entrainment), kui põhjustav sündmus kestab sama kaua kui põhjustatud sündmus; b) käivitamine (ingl launching), kui põhjustamine on seotud põhjustatud sündmuse alguspunktiga. Urpo Nikanne (1990: 188-190) formalismile tuginedes võib kaasamist ja käivitamist kokkuvõtlikult kujutada skemaatiliselt: skeemil 1 viitavad kolm punkti sellele, et antud ajastruktuuril ei ole mingit spetsiifilist vormi, ning võrdusmärk tähistab seda, et põhjustaval (T1) ja põhjustatud olukorral (T2) on ühesugune ajastruktuur; koolon skeemil 2 tähistab kahe ajapunkti vahelist vastavust.

\footnotetext{
${ }^{5}$ Põhjus esineb siiski objektina näiteks tunnet väljendava verbi põhjusstruktuuris: Jüri kardab koeri.
} 
$\mathrm{T} 1=$

$\mathrm{T} 2 \ldots$

Skeem 1. Kaasav põhjustamine (nt Jüri kannab puud sauna; Vanaisa hööveldab suuski).
$\mathrm{T} 1$

$\mathrm{T} 2$

Skeem 2. Käivitav põhjustamine (nt Jüri viskab kirve järve; Mari teeb akna lahti).

Lisaks kaasavale ja käivitavale põhjustamisele on kindlaks tehtud ka kolmas põhjustamisega seotud ajastruktuuri tüüp. Michaela Pörn (2004) on soome keele tundekausatiive analüüsides eristanud aimduse (ingl hunch, sm aavistus) alatüübi, mis viitab sellele, et põhjustatud olukord eelneb ajaliselt põhjustavale sündmusele. See on võimalik sellistel juhtudel, kui mõte eelseisvast sündmusest põhjustab mingi olukorra enne, kui olukord realiseerub (kui üldse). Näiteks toob Pörn (2004: 134) tundekausatiivi ja infinitiivtarindi ühendi Pekkaa hävettää lähteä kotiin 'Pekkal on häbi koju minna' tõlgenduses 'Pekkal on häbi (täna) koju minna (homme)'. Aimduse ajastruktuur on kirjeldatud ajajoonte ja -punktide abil skeemil 3; kooloni puudumine tähistab seda, et ajajoonte piiridel ei ole selget kokkupuutepunkti. Tundeseisundit (T2) analüüsitakse niisiis põhjustatud olukorrana ning infinitiivlaiendiga tähistatud sündmust (T1) põhjustava olukorrana.

$\mathrm{T} 1$

$\mathrm{T} 2$

Skeem 3. Aimduse tüüpi põhjustamine.

Arvestamata adjunktkonstruktsiooni kuuluvate sündmuste ajasuhteid, võib maatrikslause ja adjunktkonstruktsiooni vaheliste põhjussuhete kirjeldamiseks eristada kahte tüüpi kausatiivset alistussuhet: ühel juhul põhjustab adjunktkonstruktsioon maatriks-

lause sündmuse ja teisel juhul vastupidi, maatrikslause põhjustab adjunktkonstruktsiooni sündmuse. Neid põhjussuhteid saab väljendada kausatiivsete operaatorite ${ }^{6} \mathrm{CS} \uparrow$ ja $\mathrm{CS} \downarrow$ abil (vt Paulsen 2011: 214):

$\mathrm{CS} \uparrow$ adjunktkonstruktsioon väljendab maatrikslause olukorra põhjust (PõHJUS) $\mathrm{CS} \downarrow$ adjunktkonstruktsioon väljendab maatrikslause olukorra tagajärge (TAGAJÄRG)

\footnotetext{
${ }^{6}$ Termin operaator tähistab siin formaalsemantilise analüüsi primitiivi, millel on teatud ulatusala kas mingi sündmuse või seisundi üle.
} 
Edaspidises formaalses analüüsis püüan kirjeldada adjunktkonstruktsioonide põhjus- ja ajasuhteid kontseptuaalse semantika meetodite abil, süvenemata sealjuures sündmusstruktuuri detailidesse. Analüüsis kasutan kausatiivseid operaatoreid CS $\uparrow$ ja CS $\downarrow$. Kuna kausatiivsed operaatorid fokuseerivad põhjustamisega seotut, kirjeldan ajasuhteid ajajoone ja -punkti abil ning kasutan konstruktsioonide temporaalsete suhete eristamiseks lühendeid TM (maatrikslause ajastruktuur) ning TA (adjunktkonstruktsiooni ajastruktuur), mitte T1 (põhjustav olukord või põhjustaja) ja T2 (põhjustatud olukord) nagu skeemidel 1-3. Ajasuhete analüüs ei pürgi täielikule aspektuaalsele täpsusele, vaid jääb laiemale üldistustasemele. Järgnevalt tutvustan kahte kausatiivset alistustüüpi: peatükis 3 põhjusadjunkte ning peatükis 4 tagajärgadjunkte intransitiivsetes ja transitiivsetes lausetes ning konstruktsioonides (viimaste all mõeldakse siinkohal verbirektsioonist laiemaid skemaatilisi struktuure). Peatükis 5 keskendun otstarbeadjunktide põhjus- ja ajasuhete analüüsile. Tegemist ei ole niisiis süstemaatilise põhjusadjunktide vormi analüüsiga, vaid eesmärk on kindlaks teha alistatud põhjusstruktuuride võimalikke kausatiivseid ja temporaalseid ilminguid. Analüüsis kasutatud keelenäited on kas omaloodud, leitud internetist või Eesti Keele Instituudi peamiselt ajakirjanduskeelel baseeruvast tekstikorpusest ${ }^{7}$; mõned näited on pärit ka „Eesti keele seletavast sõnaraamatust" (EKSS).

\section{Maatrikslause põhjust väljendavad adjunktid}

\subsection{Intransitiivsed verbid ja põhjusadjunkt. Verbid surema ja sündima}

Peatükis 3 keskendun konstruktsioonidele, milles adjunkt väljendab maatrikslause põhjust. Alapeatükkides 3.1 ja 3.2 käsitlen vastavalt intransitiivseid ja transitiivseid verbe, mis esinevad tagajärje rollis. Alapeatükid 3.3 ja 3.4 lähtuvad vastavalt nominalisatsiooni või genitiivatribuuti sisaldavatest konstruktsioonidest ning essiiviga vormistatud adjunktitüüpidest.

Põhjusadjunktiga esineva intransitiivse verbi näitena vaatlen alustuseks surema-verbiga liituvaid adjunkte. See verb väljendab drastilist olukorra muutust, sündmust, mis enamasti vajab mingisugust seletust. Verbi surema semantilisse valentsi kuulub erinevat tüüpi põhjusadjunkte, ka esineb see verb mitmetes kinnistunud põhjuskonstruktsioonides. Käsitlen kõigepealt verbiga surema esinevaid kohakäändelisi põhjusadjunkte. Põhilised selle verbiga seotud põhjusadjunkti vormistavad käänded on illatiiv ja elatiiv, oma põhitähenduselt üksteisele vastandliku suunaga sisekohakäänded, mis fokuseerivad vastavalt sihtkohta ja lähtekohta. Kõigi näidetes 7 ja 7 ' esitatud sünteetiliste adjunktide asemel võib kasutada tagasõnadega tõttu, pärast, kätte, moodustatud analüütilisi adjunkte.

(7) Jokker suri mürgitusse / vanadusse / vigastusse / nälga / *mürki.

(7') Jokker suri mürgitusest / vanadusest / näljast / *vigastusest / ?mürgist.

Ka asukohakäändeid adessiiv ja inessiiv kasutatakse surema-verbiga seotud adjunktide vormistamiseks. Võrreldes illatiivi ja elatiiviga paistab asukohakäändeline põhjusadjunkt edasi andvat pigem mingis olukorras vii-

\footnotetext{
${ }^{7}$ http://portaal.eki.ee/corpus
} 
bimisest tingitud kaudsemaid põhjusi kui otsest põhjust. Lisaks hõlmab asukohakäändeline põhjusadjunkt lokatiivset, temporaalset ning kausatiivset mitmetähenduslikkust: Jokkeri suremine näites 8 on leidnud aset rindel viibimise ajal ning ilmselt ka rindel oleku tõttu; Jokker suri vangistuses ilma otsese kontekstita viitab pigem kohale või ajale kui põhjusele. Illatiiv ja elatiiv näites 8 esitatud asjaoludele viitavaid adjunkte väljendama ei sobi. Ka ei saa asukohakäändelisi põhjusadjunkte alati parafraseerida tagasõnadega (Jokker suri operatsiooni / ?rinde tõttu), mis viitabki tugevale koha- või ajatõlgendusele; võimalik on muuta kaassõnafraas näiteks samaaegsust ja -kohalisust väljendavaks des-konverbitarindiks (näiteks olema-verbiga: operatsioonil, rindel, vangistuses olles).

(8) Jokker suri operatsioonil / rindel / vangistuses.

Verbi surema maatrikslause ja adjunkti põhjussuhet ning ajastruktuuri võib kokkuvõtlikult analüüsida järgmiselt: adjunktkonstruktsioon põhjustab maatrikslauses väljendatud olukorra ning eelneb ajaliselt maatrikslause ajastruktuurile, kujutades endast käivitavat põhjustamist (vt peatükk 2). Skeemil 4 on maatrikslause ajastruktuur (TM) analüüsitud punkti abil, kuna tegemist on dünaamilise ning punktuaalset sündmust väljendava teelise (ingl telic) verbiga (aspektuaalsete verbiklasside ning tunnuste kohta vt Vendler 1967: 606-610 ja Metslang 1993: 41). Adjunktkonstruktsiooni ajastruktuur on kirjeldatud maatrikslause ajastruktuurile kronoloogiliselt eelneva lõpp-punkti sisaldava ajajoone abil.

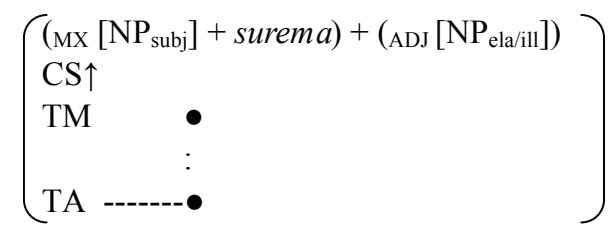

Ske e m 4. Verbi surema põhjusadjunktkonstruktsioonide analüüs.

Verb surema osaleb metafoorses tähenduses ka tunnete ülevõimendumist väljendavates infinitiivkonstruktsioonides, mille põhjusadjunkti vormistavad elatiiv või illatiiv. Üks kahest lähisünonüümsest tundevõimenduskonstruktsioonist sisaldab abiverbitaolises funktsioonis olema-verbi ja surema-verbi $m a$-infinitiivi inessiivivormi ehk mas-vormi (vt näide 9). mas-vormi võib pidada eesti keele progressiivtarindiks, millega seostuvad iseäranis saavutusverbid (vt Metslang 1993), milleks võib pidada ka verbi surema. Teise konstruktsiooni abiverb on pidama ning verb surema liitub sellega ma-infinitiivivormis (9'). Ka „tavaline” tundekausatiivkonstruktsioon verbiga surema vormistab põhjusadjunkti elatiivis või illatiivis (9"). Tundevõimenduskonstruktsioonide ühisjooneks on avertiivne funktsioon, mis Tania Kuteva (2000) määratluses tähistab aspektuaalset tähendust 'verbi poolt viidatud tegevus on peaaegu juhtumas, aga ei aktualiseeru'. Verbil pidama puuduvad selles konstruktsioonis oleviku ja täismineviku vormid (pidama-verbi avertiivsusest vt Erelt 2001); olema-verbil tundub lisaks lihtminevikule vähemalt olevikuvorm luba- 
tud olevat. Põhjustamise ajaline struktuur on tundevõimenduskonstruktsioonis kaasav, mitte käivitav, nagu surema-verbi puhul tavaliselt (vrd skeem 4). Põhjusadjunkt võib mõlemas konstruktsioonis olla nii elatiivis kui ka illatiivis; illatiivi kasutusala näib siiski mõnevõrra piiratumana. Lisaks võib mentaalset põhjust väljendada postpositsioonide kätte ja pärast abil.

(9) Olen uudishimust / uudishimusse; rõõmust / ?rõõmu / rõõmu kätte suremas.

(9') Pidin uudishimust / uudishimusse; rõõmust / *rõõmu / rõõmu kätte surema.

(9") Suren uudishimust / uudishimusse / üksindusse / *rõomu; igatsusest tema järele.

Lisaks kohakäändelistele ja kaassõnalistele adjunktidele saab suremaverbi tegevuse põhjust väljendada partitiivse adjektiivlaiendiga, mis ühildub verbi tähendusele otseselt vastava objektiga nn sisuobjektikonstruktsioonis. ${ }^{8}$ Selles konstruktsioonis on adjektiivlaiend kohustuslik, lisaks põhjusele võib laiend viidata ka tegevuse toimumise viisile:

(10) Jokker suri vägivaldset / loomulikku surma.

(10') *Jokker suri surma.

Ka verbi sündima põhjusadjunkt esineb elatiivis (näide 11) ning väljendub näiteks kaassõnade tõttu, toel, jõul ning pinnalt (12-12”) abil. Põhjusadjunkti kasutatakse elusolendi sünnile viidates (11), aga ka abstraktsemas loomistähenduses nii juhuslikku kui ka eesmärgikindlat laadi põhjust väljendades (11'). Verbi sündima laiendav põhjusadjunkt moodustab maatrikslausega põhimõtteliselt samasuguse põhjus- ja ajasuhte struktuuri kui esitatud suremaverbi liigenduses (vt skeem 4).

(11) Laps sündis armastusest / kõrvalsuhtest.

(11') Et Soome mängis kuus-null kaitset, sündis enamik Eesti väravaist kaugvisetest. (aja/epl/96/a_961125)

(12) Daniel Levi võistluslugu „Burning Lights” sündis katkise elektrisüsteemi tõttu. (http://menu.err.ee/v/eestilaul/95380d52-ce93-4181-8ccd-9cb04269f868)

(12') Firma Raktoom omanik Meelis Toom pidas oluliseks, et poe, bistroo, sauna ja külalistubadega tankla sündis kohaliku kapitali toel ja kohalike meeste jõul. (aja/epl/96/a_961125)

(12") Ka Berio sõprus Umberto Ecoga sündis Saussure’i lingvistika ja Joyce’i pinnalt. (aja/epl/96/a_960606)

Kuigi oleme vaadelnud kõigest kahte intransitiivset verbi, on märgata, et põhjusadjunkt võib tähenduslikult olla rohkem või vähem prototüüpne ning põimuda näiteks ruumilise, temporaalse, instrumendi, viisi või situatiivse tähendusega. Kas aga illatiiv kuulub ainult surema-verbi valentsi ning elatiiv on üldine põhjust väljendav kääne? Sagedusuuringutele tuginemata võib ilmselt elatiivi pidada üldisemaks põhjust väljendavaks käändeks, mis esineb ka transitiivsete verbidega (vt 3.2). Illatiivis on siiski võimalik väljendada ka mõnede teiste suremisverbide põhjusadjunkti, vrd vingu lämbuma; Kuninga

\footnotetext{
${ }^{8}$ Sisuobjekti (ingl cognate object) all mõeldakse (tavaliselt intransitiivse) verbi samatüvelist või kontseptuaalselt samatähenduslikku objekti (Mari tantsis tantsu/valssi).
} 
sõnad lämbusid nuuksumisse/pisaraisse; Viinaklaasi upub rohkem inimesi ära kui meres (EKSS).

\subsection{Transitiivsed verbid ja põhjusadjunkt}

Transitiivsete verbidega seotud sünteetiline põhjusadjunkt võib esineda elatiivis, kausatiivne võib olla ka peamiselt viisi või vahendit väljendav komitatiivadjunkt. Illatiiviga vormistatud põhjusadjunkti ei ole mul vähemalt siiani õnnestunud transitiivsete verbidega seotult leida, kuid intransitiivsete verbidega seotud põhjusadjunkt võib esineda komitatiivis (nt Mari jooksis suurest rõõmust / suure rõõmuga kolm tïiru ümber kaevu). ${ }^{9}$ Psüühilist põhjust väljendav elatiivadjunkt võib esineda näiteks verbiga palkama (näide 13); füüsilist põhjust vormistav komitatiivadjunkt (siin ka vahendi tähenduses) on esitatud näites (13').

(13) Palkasin ta upsakusest.

(13’) Mart karastas lapsi külma veega.

Kausatiivne verb on enamasti transitiivne, nagu näiteks surema-verbi transitiivne vaste, „kausatiivseim” verb tapma. ${ }^{10}$ Ka kausatiivsed verbid võivad niisiis siduda põhjusadjunkte. Agentiivne põhjustaja on kausatiivse verbi puhul tüüpiliselt väljendatud tegevussubjektiga seotud agentargumendi kaudu. Tegevusobjekti tegevuse täideviimisse kaasatud vahendit või viisi, mida võib tõlgendada ka kaudse põhjustajana, saab väljendada komitatiivis, aga ka adessiiv või kaassõnafraasid (nagu nt EKSS-ist laenatud näites 14) on võimalikud. Verbiga lõhkuma on aga võimalik ka põhjust väljendav elatiivadjunkt (15).

(14) Sü̈̈dimõistetu tapeti giljotiini all / elektritoolil / mürgisüstiga. (EKSS)

(15) Mees lõhkus käed metsatööst veriseks.

Näidete $13-13$ ' ja 15 põhjus- ning ajasuhteid võib kokkuvõtlikult kirjeldada järgmiselt: adjunktkonstruktsiooniga tähistatav sündmus põhjustab maatrikslause sündmuse; ajastruktuure kirjeldab kaasav põhjustamine ehk maatrikslause sündmus kestab sama kaua kui adjunktkonstruktsiooni sündmus, sõltumata osasündmuste aspektuaalsetest omadustest. Neid omadusi kirjeldab skeem 5, kus konstruktsiooni osade ajastruktuuridel ei ole spetsiifilist vormi ja need on üldistatud kolme punkti abil. Oluline on, et võrreldavad ajastruktuurid ühtivad, nende samasust tähistab võrdusmärk. Näites 14 on põhjustamise ajasuhe käivitav, st põhjustava sündmuse ehk adjunktkonstruktsiooni ajajoon eelneb maatrikslause ajajoonele (vt skeemi 6).

\footnotetext{
${ }^{9}$ Tänan retsensenti näite eest.

${ }^{10}$ Kuna kausatiivsust peetakse valentsi lisavaks vahendiks, siis transitiivsuskontiinumitel (vt nt Hopper, Thompson 1980) on prototüüpseima transitiivse verbi omadused tihti määravad ka kausatiivsete verbide määratlustes (transitiivsust tõstvad omadused on teelisus, punktuaalsus, mitme osavõtjarolli olemasolu, objektargumendi mõjutatavus (ingl affectedness) subjektargumendi tegevusest ning verbi kuulumine dünaamiliste sooritusverbide hulka (arutelust transitiivsuse ja kausatiivsuse määratluste üle vt nt Paulsen 2011: 80-88).
} 
Skee m 5. Kaasava põhjusadjunktkonstruktsiooni analüüs näidete 1313 ' ja 15 põhjal.

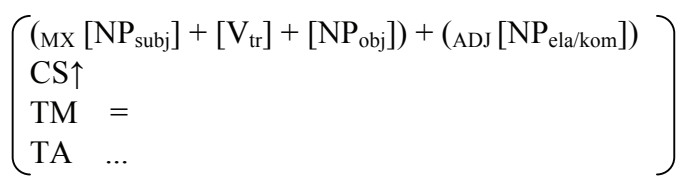

Sk e e m 6. Käivitava põhjusadjunktkonstruktsiooni analüüs näite 14 põhjal.

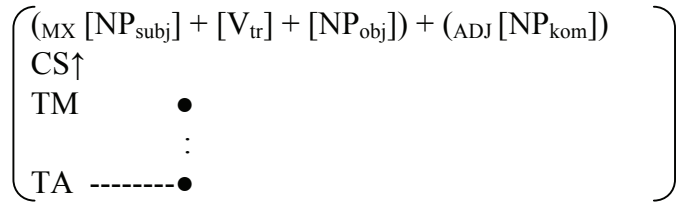

\subsection{Nominalisatsioonid ja genitiivatribuudid}

Ühe produktiivse põhjusadjunktide liigi moodustavad eesti keeles nominalisatsioone ja genitiivatribuutfraase sisaldavad konstruktsioonid, mis võivad esineda nii intransitiivsete kui ka transitiivsete verbidega. Kuna neil põhjusadjunktkonstruktsioonidel vormiliselt märkimisväärseid erinevusi ei ole, käsitlen neid siin koos. Põhjust väljendavad nominalisatsioonid on tüüpiliselt tuletatud sufiksite -mine, $-u s,-e,-u,-i,-n g,-k$ või konversiooni abil (vt Sahkai 2006, 2009). Põhjusadjunkti käändevorm nominaliseeritud konstruktsioonides on üldiselt komitatiiv (näide 16) või adessiiv (17 ja 18); kaassõnadest võib kasutada tõttu, pärast, abil, tänu (vrd 16', 17' ja 18').

(16) Mart karastas lapsi jooksmise ja ujumisega.

(16') Mart karastas lapsi jooksmise ja ujumise abil.

(17) Unepuudusel lugesin keeleteaduslikku kirjandust.

(17') Unepuuduse tõttu lugesin keeleteaduslikku kirjandust.

(18) Kuhmo fenomen sündis ühe maailmaparandaja visioonist, unistaja enda teovõimsal eestvedamisel. (aja/epl/96/a_960817)

(18') Kuhmo fenomen sündis ühe maailmaparandaja visioonist, tänu unistaja enda teovõimsale eestvedamisele.

Agentiivne põhjusadjunktkonstruktsioon, milles genitiivagent laiendab elatiivis peasõna, on esitatud näites 19. Genitiivagent on selles konstruktsioonis kohustuslik (vrd 19'). Sobiv kaassõna on selles konstruktsioonis pigem positiivset tähendusvarjundit kandev tänu kui näiteks tõttu või pärast.

(19) Eesti võitis Vassiljevi väravast poolaja.

(19') *Eesti võitis väravast poolaja.

Põhjusadjunktiga seotud genitiivatribuut vormistab tavaliselt agentargumenti ehk alusstruktuuri tegevussubjekti ka adessiivsete nominalisatsioonide korral (näited 20-20'); komitatiivtarindi genitiivatribuut aga vastab alusstruktuuri tegevusobjektile (näide 21). Adessiivse põhjusadjunkti genitiivatribuut ei ole aga agentiivne, kui alusverbi subjektiargument kannab verbi 
leksikaalses struktuuris teema rolli (näide 22). Adessiivsed nominaliseeritud põhjusadjunktid võivad esineda nii intransitiivsetes (näide 20) kui ka transitiivsetes (näited 20' ja 22) konstruktsioonides.

(20) Kogumik ilmus keeleinstituudi kirjastusel / kirjastamisel.

(20') Koolis töötasid ringid õpetajate juhendamisel.

(21) Skype'i leiutamisega odavnesid kõnehinnad.

(22) Turistide puudusel valitseb Niiluse kaldail viletsus. (http://ekspress.delfi.ee/ news/kohver/ turistide-puudusel-valitseb-niiluse-kaldailviletsus?id=70755393)

Näidete 19-21 konstruktsiooniosade ajasuhe on käivitavat laadi (vt ptk 2). Kuna ajastruktuuride täpsem analüüs ei ole käesoleva artikli põhieesmärk ning ülal esitatud verbid on aspektuaalselt erinevat tüüpi, jätan maatrikslause ja adjunktkonstruktsiooni ajajooned põhjus- ja ajasuhete skeemil 7 mitte kokkupuutuvatest otstest teeliselt määratlemata (punktideta). Nurksulud objektargumenti tähistava NP ümber märgivad elemendi valikulisust. Näidetes 16-18”, 20' ja 22 on põhjusahelas osalevad sündmused kaasava ehk samaaegse temporaalse iseloomuga. Nominalisatsioonkonstruktsioonid võivad niisiis väljendada nii kaasavat kui ka käivitavat põhjustamist.

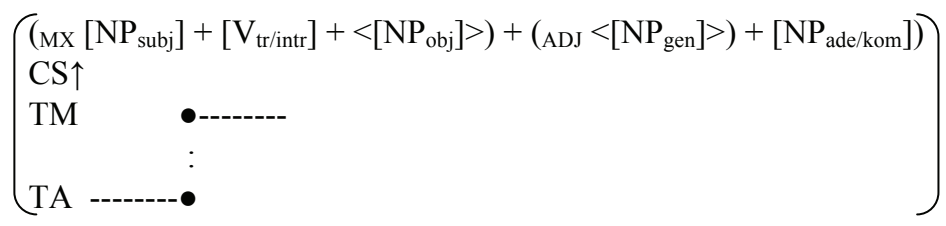

Sk e e m 7. Käivitava põhjusadjunktkonstruktsiooni analüüs näidete 19-21 põhjal.

Nii adessiivse kui ka komitatiivse nominalisatsiooni antonüümse põhjusadjunktina saab kasutada abessiivi, vt näited 23-23'. Abessiivadjunkt on sisult eitava polaarsusega ning vajab mõnikord põhjustamistähenduse aktiveerimiseks verbi eitusvormi - näiteks lause (23) jaatavas versioonis (vt 23') abessiivadjunkt põhjustamist ei väljenda, kui lisame fookuspartikli $k a$ (partiklite funktsioonidest ja jaotusest vt Hennoste 2000), mis lisab propositsioonile välistava järelduse (Skype või Skype’i leiutamine ei mõjuta kõnehindade odavnemist). Abessiivadjunkt võib siiski ka jaatavas lauses põhjust väljendada (24), kuid ei pruugi (24').

(23) (Ilma) Skype'ita / Skype’i leiutamiseta kõnehinnad ei (oleks) odavnenud.

(23') Kõnehinnad odavnesid ka (ilma) Skype’ita / Skype’i leiutamiseta.

(24) Nokiata langes Soome majanduskasv nulli / Päästevestita upud / Soolata on supp parem..$^{11}$

(24') Koolis töötasid ringid (ilma) õpetajate juhendamiseta.

${ }^{11}$ Tänan näidete 24, 24' eest Heete Sahkaid. 


\subsection{Geneeriline põhjusadjunkt}

Eraldi mainimist väärib maatrikslause põhjust väljendavate adjunktide puhul geneeriline kaasavat tüüpi põhjustamine. Kuna kausatiivsust on enamasti määratletud sündmuste, mitte seisundite vahelise suhtena, on geneeriline kaasav põhjusadjunkt kausatiivsusteooriate vaatenurgast erandlik nähtus. Tegemist on niisiis kahe seisundi vahelise tingiva suhtega, milles tüüpiliselt on põhjustav seisund staatiline ja põhjustatud seisund dünaamiline. ${ }^{12}$ Geneerilisse põhjuskonstruktsiooni kuuluvate seisundite kesksed omadused on järgmised: üks seisund põhjustab teise seisundi püsimise, põhjustatud seisund on habituaalne ehk toimub „tavaliselt”, mõlemad seisundid on geneerilised (imperfektiivsed), neutraliseerides aspektuaalsed erisused (vt Dahl 1995), ning aeg on irrelevantne (mõeldavalt on seisundite ajajoon ühine, määramata algus-, lõpp- või keskpunktiga). Eesti keeles võivad seda tüüpi kirjeldavad adjunktid esineda essiivis, väljendades elusa osalejaargumendi staatust või rolli. Essiivis vormistatud põhjusadjunkt viitab niisiis habituaalsetele ja duratiivsetele olukordadele, väljendades tinglikult tähendust 'kuna $\mathrm{X}$ on $\mathrm{Y}$, olukord Z säilib'. Essiivadjunkt võib esineda nii transitiivsete kui ka intransitiivsete verbidega, vt näiteid 25, 25’:

(25) Ajakirjanikuna kohtub Mats paljude inimestega.

(25’) Ópetajana loen kasvatusalast kirjandust.

Geneerilise põhjusadjunkti analüüsis (skeem 8) lisan senistele põhjus- ja ajasuhteid kirjeldavatele operaatoritele Pörni (2004: 65-66) kasutusele võetud habituaalsust tähistava operaatori HAB. ${ }^{13}$ Kuna adjunktkonstruktsioon põhjustab maatrikslause olukorra, tähistan põhjussuhet $\mathrm{CS} \uparrow$-operaatoriga; ajasuhe on kaasav, kuna põhjustatud olukord kestab sama kaua kui põhjustav olukord.

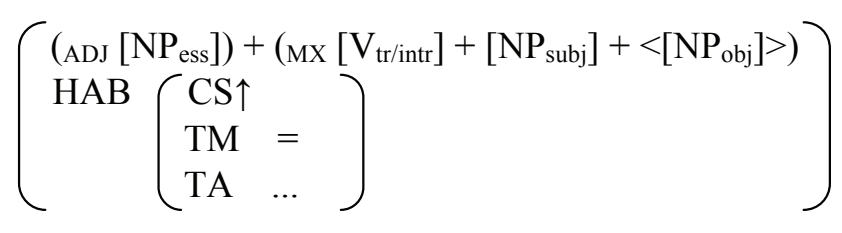

Sk e e m 8. Geneerilise põhjusadjunktkonstruktsiooni analüüs.

Essiiv ei ole siiski ainuke võimalik geneerilise põhjusadjunkti kääne: ka adessiivis võib väljendada püsivat põhjusseisundit, nagu näites 26 , mis pärineb ajalehe Postimees veebiversiooni artikli päisest.

\footnotetext{
${ }^{12}$ Seisundid ei ole homogeenne klass, vaid neid võib jagada kahte ontoloogiliselt erinevasse rühma: dünaamilised seisundid ehk nn Davidsoni seisundid sisaldavad sündmuslikku komponenti (nn peidetud sündmusargumenti), nagu näiteks verbide magama, seisma, istuma puhul; staatilisi seisundeid ehk Kimi seisundeid väljendavad koopulalaused ning verbid, nagu teadma, kaaluma, omama (vt Davidson 1967; Kim 1969; Dowty 1979; Bach 1981; Maienborn 2003; Paulsen 2012).

${ }^{13}$ Võrdluseks tuleks mainida, et Jackendoff (1991) tähistab geneerilist ja dünaamilist olukorda PL-operaatoriga, ingl plural 'mitmuslik'.
} 
(26) Ega rahandusministrist suurt sõltugi, sest Eesti püsib ametnikel (http://majandus24.postimees.ee/2968761/mois-ligi-oli-ministrina-keskparane)

Geneerilist põhjusadjunkti väljendavale sünteetilisele vormile vastav analüütiline vorm vajab täiendavat nimisõnalist (nominaliseeritud) laiendit ning mõjub konstrueeritult ja kohmakana (ajakirjanikuks olemise tõttu/ajakirjaniku ameti tõttu/ametnike olemasolu tõttu). Loomulikum oleks parafraas põhjendavate (ühend)sidendite kuna või sellepärast et abil moodustatud predikatiivses kõrvallauses, nt Kuna Mats on ajakirjanik, kohtub ta paljude inimestega.

Essiivadjunkti kasutusala on geneerilisuse väljendamisest mõistagi laiem, sellega võib tähistada ka puhtalt temporaalset suhet maatrikslausesse (näide 27) ning põhjustatud seisund võib viidata teelisele sündmusele, kui on mõeldud konkreetset ja piiritletud olukorda (näide 27'). Geneerilise põhjustähenduse loomisel on niisiis tähtis roll nii lause- kui ka tekstikontekstil (habituaalset tõlgendust toetavad näiteks adverbiaalid palju, sageli, alati).

(27) Noorena tegelesin kergejõustikuga.

(27') Meedikuna oskab ta hädasolijat aidata.

\section{Maatrikslause tulemust väljendavad adjunktid. Resultatiivsed tagajärgadjunktid}

Resultatiivse konstruktsiooni tulemusfraas on selgeim tagajärgadjunkti tüüp, milles maatrikslause sündmus põhjustab adjunktkonstruktsiooniga väljendatud olukorra. Resultatiivkonstruktsiooni peaverb võib olla nii kausatiivne (näited 28, 29) kui ka mittekausatiivne (näited 28', 29'). Maatrikslause on tagajärgadjunkti põhjuseks, olenemata sellest, kas verb on kausatiivne või mitte. Kuna resultatiivkonstruktsiooni võib nagu kausatiivkonstruktsioonigi pidada valentsi lisavaks predikatsiooniks (või argumentstruktuuri määravaks konstruktsiooniks, vt Goldberg 1995), mis võimaldab intransitiivsete verbide transitiivset kasutust, võivad objekti saada nii transitiivsed (näited 28, 29) kui ka intransitiivsed (28') verbid. Tulemust väljendavas lauses võib aga objekt ka puududa (näide 29') ja maatrikslause saab siiski olla adjunktkonstruktsiooniga väljendatud olukorra põhjuseks. Transitiivse ja intransitiivse resultatiivse konstruktsiooni erinevuseks on, et esimesel juhul on tulemusfraasil predikatiivne suhe objektiga ja teisel juhul subjektiga. Tulemusseisund võib olla märgitud translatiivis (28'), allatiivis (29) või illatiivis (28); lisaks võib kasutada erinevaid tulemust väljendavaid adverbe, nagu ümber, pikali, laiaks.

(28) Löök paiskas mehe porri/vette.

(28') Lumi sadas teed libedaks.

(29) Uksekell ajas vanaisa jalule.

(29') Veinipudel kukkus sillutisele kildudeks.

Põhjus- ja ajasuhete analüüsis võib resultatiivsed konstruktsioonid üldistada kahte rühma: duratiivsed ja punktuaalsed sündmused. Duratiivsete sündmuste puhul võib predikaadi aspektuaalseid omadusi mõjutada nn kas- 
vava teema (ingl incremental theme, vt Dowty 1991) esinemine, mis viitab teema referendiga toimuva muutuse järkjärgulisele iseloomule (nt Poiss sööb õuna, vrd ka näitega 28'). Nii ei lähe jalad näites 30 rakku esimeste kõnnitud sammudega, vaid rakkude tekkimine ja hõõrdumise süvenemine korreleerub teekonna pikkusega. Märgin maatriks- ja adjunktkonstruktsiooni ajajooned skeemil 9 seetõttu osaliselt kattuvaiks. Tegemist ei ole niisiis selgelt käivitava ega kaasava põhjustamisega, vaid seda tüüpi põhjustamist võiks nimetada osaliselt kattuvaks käivitamiseks või kasvavaks põhjustamiseks.

(30) Kristjan Jaak kõndis jalad rakku.

(30') Aednik kastis tulbid pikali.

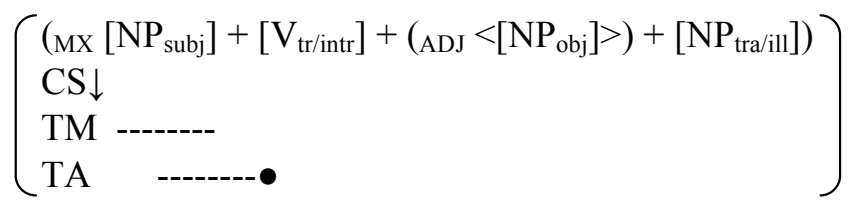

Sk e e m 9. Kasvava põhjustamise tagajärgadjunktkonstruktsiooni analüüs.

Maatrikslause ja adjunktkonstruktsiooni ajasuhted võivad resultatiivses lauses olla ka selgelt piiritletud (vt näiteid 31 ja $31^{\prime}$ ). Kui tulemusfraasi ajastruktuur on punktuaalne, on tegu käivitavat tüüpi temporaalse suhtega ja põhjustav sündmus (TM) on seotud põhjustatud sündmuse (TA) toimumishetkega (skeem 10).

(31) Äike müristas lapsed üles / ärkvele.

(31’) Soome võit lükkas Venemaa kuristiku äärele.

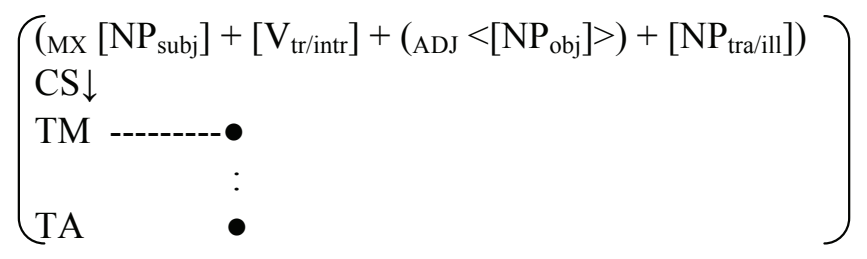

Ske e m 10. Käivitava põhjustamise tagajärgadjunktkonstruktsiooni analüüs.

\section{Otstarbeadjunktid. Kahesuunaline põhjustamine}

Otstarvet või eesmärki väljendavad adjunktid on kausatiivsuse ja temporaalsuhete kirjeldamise vaatenurgast keerukas juhtum. Kuna otstarbeadjunkt väljendab nii maatrikslauses viidatud tegevuse põhjust kui ka (mitte tingimata realiseeruvat) tagajärge, on tegemist kahesuunalise põhjussuhtega: kavatsetav (mittefaktuaalne) olukord põhjustab maatrikslause sündmuse ning 
viimane põhjustab omakorda adjunktistruktuuris väljendatud olukorra teostumise. Subjektargumendi agendiomadustel on otstarbeadjunktide semantikas keskne roll, kuna tegevuse liikumapanevaks jõuks on tahtlik ja teadlik kavatsus. Otstarbelause tagajärgsündmust võiks nimetada tinglikult oodatavaks tulemuseks. Otstarbelause kujutab endast niisiis põhjuslikku ringi: adjunktkonstruktsioon on otsustavaks kaasaaitavaks faktoriks (Neelemani ja van de Kooti (2012) mõistes) maatrikslause sündmuse toimumisele ning vastupidi, maatrikslauses väljendatud tegevus aitab kaasa adjunktkonstruktsioonis väljendatud sündmuse (kavatsetud saavutuse) toimumisele (viimase realiseerumine ei ole otstarbelauses kindel).

Ühe otstarbeadjunkti sisaldava lause tüübina võiks eristada sihtkoha-otstarbekonstruktsiooni, mis koosneb lisaks otstarbeadjunktile ka asukohta väljendavast adjunktist. Sihi sünteetiliseks vormiks selles konstruktsioonis on tüüpiliselt illatiiv või allatiiv ja otstarvet vormistab allatiiv; predikaatverb on tavaliselt intransitiivne liikumisverb. Sihtkoht ja otstarve võivad olla tähistatud sama käändelõpuga (näide 32'), kuid ei pea (näide 32). Sihtkoha-otstarbekonstruktsioonis võib kummagi adjunkti välja jätta, rikkumata lause grammatilisust, kuid põhjusotstarbe tähendus on tugevam, kui lokatiiv on märgitud: kui ruumiline positsioon on täpsustatud, määratleb otstarbeadjunkt põhjust, miks subjektargument selles kohas viibib. Otstarvet võib selles konstruktsioonis tähistada ka postpositsioonidega pärast, jaoks, tarbeks, tarvis, eesmärgil, nimel, tõttu.

(32) Tädi Agata läheb haiglasse uuringutele.

(32') Astronaut lendab Kuule uurimistööle.

Transitiivsete verbidega esinevaid otstarbeadjunkte saab vormistada translatiiviga. Translatiivotstarve viitab, nagu sihtkoha-otstarbekonstruktsiooni otstarbeadjunktki, dünaamilistele olemitele, sündmustele või üritustele (vt näiteid 33-33'). Tähenduselt transitiivsele otstarbefraasile lähedane on allatiivset vastuvõtjaadjunkti sisaldav konstruktsioon (Mart kogus raha emale / ema jaoks). Üks erinevus otstarbeadjunktiga on see, et postpositsiooni jaoks ei saa otstarbeadjunktiga seoses alati kasutada (*jõulude jaoks, vrd festivali jaoks). Allatiiviga aga situatiivseid otstarbeadjunkte tähistada ei saa (valmistas vorste *jõuludele / *kogus raha festivalile).

(33) Tädi Agata valmistab vorste jõuludeks.

(33’) Mart kogub raha puhkuseks.

Ülal käsitletud otstarbelauseid iseloomustavad põhjus- ja ajasuhted on kirjeldatud skeemil 11. Põhjussuhete kahesuunalisust tähistavad mõlemad kausatiivsed operaatorid ning maatrikslause ajajoon eelneb adjunktkonstruktsiooni ajajoonele, mis on piiratud nurksulgudega valikulisuse (faktuaalse ja mittefaktuaalse interpretatsiooni) tähistamiseks. Kuna põhjussuhted on kahesuunalised, võib ajasuhet iseloomustada nii aimduse tüüpi olukorrana (põhjustav sündmus on põhjustatud sündmuse suhtes tulevikus) kui ka käivitava olukorrana (põhjustav sündmus eelneb ajaliselt põhjustatud sündmusele). 


$$
\left(\begin{array}{l}
\left(\mathrm{Mx}\left[\mathrm{NP}_{\text {subj }}\right]+\left[\mathrm{V}_{\text {intr }}\right]\right)+\left(\mathrm{LOK}<\left[\mathrm{NP}_{\text {ill/all }}\right]>\right)+\left(\mathrm{ADJ}\left[\mathrm{NP}_{\mathrm{all}}\right]\right) \\
\left(\mathrm{Mx}\left[\mathrm{NP}_{\text {subj }}\right]+\left[\mathrm{V}_{\text {tr }}\right]+\mathrm{NP}_{\text {obj }}\right)+\left(\mathrm{ADJ}_{\mathrm{Ar}}\left[\mathrm{NP}_{\text {tra }}\right]\right) \\
\mathrm{CS} \uparrow / \mathrm{CS} \downarrow \\
\mathrm{TM}-\mathrm{------ \bullet} \\
\mathrm{TA} \quad<\bullet-------\bullet>
\end{array}\right)
$$

Sk e e m 11. Otstarbeadjunktkonstruktsioonide analüüs.

Otstarbeadjunkt võib aga väljendada ka faktuaalset olukorda, nagu näites 34, mille sündmusahelat võib parafraseerida järgmiselt: Tädi Agatal on luuhõrenemine $\rightarrow$ Tädi Agata võtab tableti.

(34) Tädi Agata võtab tableti luuhõrenemise vastu.

Faktuaalse sündmuse korral on tegemist nn eemaldamisprotsessiga, mille oodatav tulemus on antud juhul agendi (tädi Agata) kogetud seisundi kõrvaldamine (nimetagem seda tüüpi otstarbeadjunkti eemaldamisotstarbeks). Lauset 34 võib aga tõlgendada ka nii, et otstarbeadjunkt väljendab mittefaktuaalset olukorda: Tädi Agatal ei ole luuhõrenemist $\rightarrow$ Tädi Agata võtab tableti $\rightarrow$ Luuhõrenemist ei teki. Sellisel juhul on tegemist ärahoidmisprotsessiga; võime seda tüüpi otstarvet nimetada vältimisotstarbeks. Lause 34 faktuaalset tõlgendust aluseks võttes võib otstarbeadjunktide kahesuunalist põhjus- ja ajastruktuuri osadeks jaotatuna kujutada nagu skeemidel 12 ja 13.

Skeem 12. Adjunktkonstruktsioon põhjustab maatrikslause sündmuse (Tädi Agatal on luuhõrenemine $\rightarrow$ Tädi Agata võtab tableti).

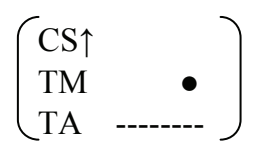

Skeem 13. Maatrikslause viib adjunktkonstruktsiooni teostumiseni (Tädi Agata võtab tableti $\rightarrow$ Tablett eemaldab luuhõrenemise).

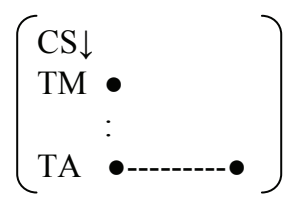

\section{Kokkuvõte}

Põhjustamisega seotud küsimused on märksa mitmetahulisemad, kui süntaktilise tuletusprotsessiga piiritletud määratlus laseb arvata. Mõistmaks selle inimtunnetusele nii fundamentaalse nähtuse olemust, tuleks ka keeleteaduses läheneda põhjuse-tagajärje suhete mõistestamisele laiemalt ning võtta arvesse, et kausatiivsusel on väljaspool tuumlause piire vähemalt sama rikkalikult tähendus- ja vorminüansse kui tuumlauses. 
Siinses uurimuses olen keskendunud adjunktkonstruktsioonide küllaltki lihtsustatud põhjus- ja ajasuhete analüüsile kontseptuaalse semantika metodoloogia raames, välja olen jätnud teised kausatiivse tähenduse loomisel osalevad tegurid. Olen püüdnud näidata, et need relatsioonid on pigem mittelineaarset kui lineaarset laadi - ei saa oletada, et põhjus- ja ajastruktuurid oleksid keeles automaatselt üksteisele üksüheselt vastavad. See tähendab, et põhjustav struktuur ei eelne tingimata temporaalselt põhjustatud struktuurile, vaid esineb ka kattumisi (kaasavat põhjustamist) ning põhjustav struktuur võib temporaalselt hoopis järgneda põhjustatud struktuurile (aimduse tüüpi põhjustamine).

Alistatud konstruktsioonis osalevad adjunktid olen jaganud põhjustamise suuna põhjal kahte üldisemasse rühma, põhjus- ja tagajärgadjunktideks. Analüüs osutas, et põhjusadjunktide puhul esineb Jackendoffi (1990) eristatud kaasavat ja käivitavat põhjustamist, otstarbeadjunktid võivad lisaks käivitavale tüübile väljendada ka aimduse tüüpi (Pörn 2004) põhjustamist ning tagajärgadjunktid osaliselt kaasavat ehk kasvavat põhjustamist. Viimane temporaalne põhjustamistüüp on üks käesoleva uurimuse leide. Põhjus- ja tagajärgadjunkti erijuhtumiks osutusid otstarbeadjunktid, mis loovad „põhjusringi", kus kavatsetav olukord järgneb kronoloogiliselt peaverbiga väljendatud tegevusele, kuid kavatsus on tegevuse liikumapanevaks jõuks, põhjustades tegevuse, mis omakorda viib soovitud olukorra saavutamiseni. Erinevaid põhjus- ja tagajärgadjunkte vaadeldes selgus, et peaverbi süntaktilised omadused mõjutavad mingil määral ka adjunkti vormi valikut. Nii intransitiivsed kui ka transitiivsed verbid võivad vormistada põhjust elatiivis; illatiiv on intransitiivsete verbide ning komitatiiv transitiivsete verbide põhjusadjunkti kääne. Kohakäändelise adjunkti puhul võib põhjustähendus muutuda kaudsemaks, olles läbi põimunud näiteks aja-, viisi-, koha- või situatiivse tähendusega. Otstarbeadjunkte saab intransitiivses lauses vormistada allatiivis ja transitiivses lauses translatiivis. Perifeerne kausatiivsus avaldub erinevates konstruktsioonides ning põhjustähendus võib aktiveeruda mingis kinnistunud süntaktiliste ja semantiliste komponentidega struktuuris (selles artiklis on esile toodud nt tundevõimenduskonstruktsioon, sisuobjektikonstruktsioon, geneerilise põhjusadjunkti konstruktsioon).

Kahtlemata puudutab käesolev artikkel kõigest perifeerse põhjustamisega seotud küsimuste pinnapealset osa. Põhjusadjunktide semantika ja süntaksi põhjalikum uurimine aitaks selgitada ka neile lähedalseisvate struktuuride, nagu näiteks koha-, viisi-, aja-, otstarbe- ja tingimusmääruste, põhjustamisega seotud tähendusnüansse. Kausatiivsete alistusvormidega seotud käändevormide uurimine annab uut teavet ka eesti keele käändesemantika kohta. Täpsemalt tuleks välja selgitada, millised käändevormid ja kaassõnad loovad põhjus-, millised tagajärgsuhet. Sünteetiliste ja analüütiliste vormide omavahelise dünaamika uurimine aitab avardada meie ettekujutust nende tüpoloogiliselt oluliste nähtuste mõjust eesti keele arengutendentsidele ning staatusele suhtes teiste keeltega.

Artikkel on valminud Eesti Keele Instituudis Haridus- ja Teadusministeeriumi baasfinantseerimise toel. 


\section{Tekstinäidete allikad}

Eesti Keele Instituudi tekstikorpus. http://portaal.eki.ee/corpus

EKSS = Eesti keele seletav sõnaraamat. Toim Margit Langemets, Mai Tiits, Tiia Valdre, Leidi Veskis, Ülle Viks, Piret Voll. Tallinn: Eesti Keele Sihtasutus, 2009. http://www.eki.ee/dict/ekss/ekss.html

\section{Kirjandus}

B a c h, Emmon 1981. On time, tense, and aspect: An essay in English metaphysics. - Radical Pragmatics. Toim Peter Cole. New York: Academic Press, lk 62-81.

Croft, William 1991. Syntactic Categories and Grammatical Relations: The Cognitive Organization of Information. Chicago: University of Chicago Press.

Croft, William 1998. The structure of events and the structure of language. The New Psychology of Language: Cognitive and Functional Approaches to Language Structure. Toim Michael Tomasello. Mahwah, NJ: Lawrence Erlbaum Associates, lk 67-92.

Croft, William 2009. Aspectual and causal structure in event representations. Routes to Language Development: In Honor of Melissa Bowerman. Toim Virginia Gathercole. Mahwah, NJ: Lawrence Erlbaum Associates, lk 139-166.

Dahl, Östen 1995. The marking of the episodic/generic distinction in tense-aspect systems. - The Generic Book. Toim Greg N. Carlson, Francis Jeffrey Pelletier. Chicago: University of Chicago Press, lk 412-425.

David s o n, Donald 1967. The logical form of action sentences. - The Logic of Decision and Action. Toim Nicholas Recher. Pittsburgh: University of Pittsburgh Press, lk 81-120.

Dix o n, Robert M. W. 2000. A typology of causative: Form, syntax and meaning. - Changing Valency: Case Studies in Transitivity. Toim Robert M. W. Dixon, Alexandra Y. Aikhenvald. Cambridge: Cambridge University Press, lk 30-79.

D ow ty, David 1979. Word Meaning and Montague Grammar. Dordrecht: Kluwer.

Dow ty, David 1991. Thematic proto-roles and argument selection. - Language, nr 67, lk 547-619.

EKG II = Mati Erelt, Reet Kasik, Helle Metslang, Henno Rajandi, Kristiina Ross, Henn Saari, Kaja Tael, Silvi Vare, Eesti keele grammatika II. Süntaks. Lisa: Kiri. Tallinn: Eesti TA Keele ja Kirjanduse Instituut, 1993.

Erelt, Mati 2001. Some notes on the grammaticalization of the verb pidama in Estonian. - Estonian Typological Studies V. (Tartu Ülikooli eesti keele õppetooli toimetised 18.) Toim M. Erelt. Tartu: Tartu Ülikooli Kirjastus, lk 7-25.

Erelt, Mati 2013. Eesti keele lauseõpetus. Sissejuhatus. Öeldis. (Tartu Ülikooli eesti keele osakonna preprindid 4.) Tartu: Tartu Ülikool.

Erelt, Mati 2014. Eesti keele lauseõpetus. Komplekslause. Tartu Ülikooli eesti keele osakond. Tartu: Tartu Ülikool.

Foley, William, A., van Valin, Robert D. 1984. Functional Syntax and Universal Grammar. Cambridge: Cambridge University Press.

Gold ber g, Adele 1995. Constructions: A Construction Grammar Approach to Argument Structure. Chicago: University of Chicago Press.

Hennoste, Tiit 2000. Sissejuhatus suulisesse eesti keelde IV. Suulise kõne erisõnavara III. Partiklid. - Akadeemia, nr 8, lk 1172-1806. 
Hopper, Paul J., Thompson, Sandra A. 1980. Transitivity in grammar and discourse. - Language, nr 56, lk 251-299.

Jackend off, Ray 1987. The status of thematic relations in linguistic theory. Linguistic Inquiry, nr 18, lk 369-411.

J a ckend off, Ray 1990. Semantic Structures. Cambridge, MA: MIT Press.

J a c k e n d off, Ray 1991. Parts and boundaries. - Cognition, kd 41, nr 1-3, lk 9-45.

Jackend off, Ray 1997. The Architecture of the Language Faculty. Cambridge, MA: MIT Press.

Jackendoff, Ray 2010. Meaning and the Lexicon. The Parallel Architecture 1975-2010. Oxford: Oxford University Press.

Kasik, Reet 2001. Analytic causatives in Estonian. - Estonian: Typological studies V. (Tartu Ülikooli eesti keele õppetooli toimetised 18.) Toim Mati Erelt. Tartu: Tartu Ülikooli Kirjastus, lk 77-122.

Ka s ik, Reet 2014. Komplekssete sõnade tähendus. Eesti sõnamoodustuse onomasioloogiline kirjeldus. Tartu: Tartu Ülikooli eesti keele osakond.

Ka s i k, Reet 2015. Sõnamoodustus. (Eesti keele varamu I.) Tartu: Tartu Ülikooli Kirjastus.

Kim, Jaegwon 1969. Events and their descriptions: some considerations. - Essays in Honor of Carl G. Hempel. Toim Nicholas Resche. Dordrecht: Reidel, lk 198-215.

Kuteva, Tania 2000. TAM-Auxiliation and the Avertive Category in Northeast Europe. Areal Grammaticalization and Cognitive Semantics: The Finnic and Sami Languages. Toim Jocelyne Fernandez-Vest. Tallinn-Paris: OURAL/ URAL, lk 27-41.

Lang, Ewald, Maienborn, Claudia, Fabricius-Hansen, Cathrine 2003. Modifying Adjuncts. Berlin: Mouton de Gruyter.

L a n g a cker, Ronald W. 1991. Foundations of Cognitive Grammar II: Descriptive Application. Stanford: Stanford University Press.

M a i e n b or n, Claudia 2003. Against a Davidsonian analysis of copula sentences. - NELS 33 Proceedings. Toim Makoto Kadowaki, Shigeto Kawahara. Amherst: GLSA, lk 167-186.

Mets lang, Helle 1993. Kas eesti keeles on olemas progressiiv? - Keel ja Kirjandus, nr 6, lk 326-334; nr 7, lk 410-416.

N e ed ha m, Stephanie, T oi v on en, Ida 2011. Derived Arguments. - Proceedings of the LFG11 Conference 2011. Toim Miriam Butt, Tracy Holloway King. Stanford, CA: CSLI Publications, lk 401-421.

Neeleman, Ad, van de Koot, Hans 2012. The linguistic expression of causation. - The Theta System: Argument Structure at the Interface. Toim Martin Everaert, Marijana Marelj, Tal Siloni. Oxford, UK: Oxford University Press, lk 20-51.

Nikanne, Urpo 1990. Zones and Tiers. Helsinki: Suomalaisen Kirjallisuuden Seura.

Nika nne, Urpo 1997. Suomen infiniittisten adjunktien temporaalinen tulkinta. - Virittäjä, nr 3, lk 338-357.

Nikanne, Urpo 2008. Conceptual semantics. - Handbook of Pragmatics. Toim Jan-Ola Östman, Jef Verschueren, Eline Versluys. Amsterdam: John Benjamins, lk 1-21.

Paulsen, Geda 2011. Causation and Dominance: A Study of Finnish Causative Verbs Expressing Social Dominance. Turku: Åbo Akademi University Press. 
Paulsen, Geda 2012. Static and dynamic states: the case of Estonian stative colour expressions. - Eesti ja soome-ugri keeleteaduse ajakiri ESUKA, kd III, nr 1 , lk 9-46.

Pa uls en, Geda 2013. Keel meeles: kontseptuaalsest semantikast. - Eesti ja soome-ugri keeleteaduse ajakiri ESUKA (Teoreetiline keeleteadus Eestis III), kd IV, nr 1, lk 73-94.

Plado, Helen 2013. Kausaalsuhete adverbiaallaused eesti keeles. Tartu: Tartu Ülikooli Kirjastus.

Pla d o, Helen 2015. des- ja mata-konverbi kasutusest eesti murretes. - Emakeele Seltsi aastaraamat 60 (2014). Tallinn: Teaduste Akadeemia Kirjastus, lk 195218.

Pör n, Michaela 2004. Suomen tunnekausatiiviverbit ja niiden lausemaiset täydennykset. Helsinki: Suomalaisen Kirjallisuuden Seura.

Pörn, Michaela 2008. Psychophysical and physical causative emotion verbs in Finnish: The temporal structure of causative emotion verb + infinitive 1 -constructions within conceptual semantics. - SKY Journal of Linguistics, nr 21, lk 201-218.

Sahkai, Heete 2006. Konstruktsioonipõhise keelekirjelduse võimalustest adessiivse viisi- ja põhjusmääruse näitel. - Keel ja Kirjandus, nr 10, lk 816-831.

S a h k a i, Heete 2009. Implications of a construction for the theory of grammaticalization: Estonian adessive manner and cause adverbials. - Trames: Journal of the Humanities and Social Sciences, kd 13, nr 4, lk 374-400.

Shibatani, Masayoshi 1976. The grammar of causative constructions: A conspectus. - The Grammar of Causative Constructions. (Syntax and Semantics 6.) Toim Masayoshi Shibatani. New York: Academic Press, lk 43-116.

Talmy, Leonard 1976. Semantic causative types. - The Grammar of Causative Constructions. (Syntax and Semantics 6.) Toim Masayoshi Shibatani. New York: Academic Press, lk 43-116.

Talmy, Leonard 1988. Force dynamics in language and cognition. - Cognitive Science, nr 12, lk 49-100.

Tomasello, Michael 1999. The Cultural Origins of Human Cognition. Cambridge, MA: Harvard University Press.

Uu s p õld, Ellen 1966. Määrusliku des-, mata-, nud- ( nuna-) ja tud- ( tuna-) konstruktsiooni struktuur ja tähendus. - Keele modelleerimise probleeme I. (Tartu Riikliku Ülikooli toimetised 188.) Tartu: Tartu Riiklik Ülikool, lk 1-196. Uuspõld, Ellen 1980. maks-vorm ja teised finaaladverbiaalid. - Keel ja Kirjandus, nr 12, lk 729-736.

Vendler, Zeno 1967. Verbs and times. - Linguistics in Philosophy. Ithaca-London: Cornell University Press, lk 97-121. 


\section{On peripheral causativity}

Keywords: Estonian, causativity, causative adjuncts, temporal structure

Causation is generally defined through its valency-increasing property to bring an additional causer argument onto a basic clause, restricting the focus of research on the verbal predicates and the core sentence. This study argues for the inclusion of the forms belonging outside the core sentence to the scope of linguistic causation. The article discusses the subordinate structures or adjuncts that have a causative relationship to the matrix sentence within the conceptual semantics framework. A two-way causative relationship between the matrix sentence and the adjunct structure is proposed: (i) the adjunct structure causes the situation in the matrix sentence (the BEACUSE OF relation), and (ii) the matrix sentence causes the adjunct's situation (the LEAD TO relation). The former type of causative subordinate structures is named the reason-adjuncts and the latter as the result-adjuncts.

The examination of causative adjuncts is based on the causative expressions in Estonian. The analysis reveals that causal and temporal relationships do not display a 1:1 relationships in the sense that the causing event always precedes the caused event chronologically. The Jackendovian (1990) causa-temporal types entrainment and launching are represented in the case of reason-adjuncts; in connection with purpose-adjuncts the hunch-causation proposed by Pörn (2004) occurs beside launching; the incremental causation or partial entrainment type, introduced in this paper, occurs in connection with result-adjuncts. The purposeadjuncts show a particularly complicated causal-temporal configuration, a bidirectional causative relationship: the desired event (the temporally latter event) is the reason behind the activity denoted by the core verb and the activity denoted by the matrix sentence causes the intended event. The present study also points to the tendency that illative case is used in connection with intransitive verbs and comitative in connection with transitive verbs conveying causation in Estonian; elative is a "universal" causative case in the sense that it combines both with transitive and intransitive verbs.

The preliminary examination suggests that a comprehensive account of the subordinate structures is needed in order to explain the „causative content” of different types of adjuncts like e.g. causative, manner, instrumental, purpose, conditional and temporal adjuncts. Regarding the research of Estonian, an investigation of causative adjuncts would contribute to the elaboration of the semantico-syntactic behaviour of synthetic vs. analytic linguistic forms.

Geda Paulsen (b. 1973), PhD, Institute of the Estonian Language, Senior Lexicographer, geda.paulsen@eki.ee 